\title{
THE BERLUSCONI GOVERNMENT'S FOREIGN POLICY: THE FIRST 18 MONTHS
}

\author{
Filippo Andreatta and Elisabetta Brighi
}

Italian foreign policy has always been greatly influenced by the country's domestic politics. Certain important historical processes have made it considerably difficult to separate the country's external representation from its domestic political equilibria. This state of affairs has had a considerable bearing on Italy's international standing, which has been inhibited and therefore weakened as a result. The country's fragile national tradition, the legacy of a ruinous dictatorship, and, in particular, the instability of the government, which underlies the very nature of the proportional electoral systemtogether with the existence of the largest communist party outside the Soviet bloc-have hindered the formation of a bipartisan consensus and of a foreign policy free from domestic pressures.

During the Cold War, the government surprisingly managed to establish the country within the Western network of alliances, although it had to keep a rather low profile in order not to face proSoviet flak. After the end of the Cold War and the disintegration of the Italian Communist Party (PCI), Italian foreign policy entered a new phase, whereby most of the country's left embraced a new activism within traditional multi-lateral European, Western, and UN-based forums. Wide support was given to Italy's involvement in military 
intervention in Bosnia, Albania, and Kosovo. In the last two cases, though, the center-left government's actions were strongly influenced by the staunch opposition of the extreme left, which would have brought the government down, had the center-right opposition not providentially come to its aid.

The landslide victory of the Casa delle Libertà in the 2001 general election still left some questions unanswered with regard to these critically important issues. On the one hand, the center-right was, just like the center-left, a heterogeneous coalition in danger of falling apart over foreign policy. The Northern League adopted a strong anti-European and anti-Western stance, which culminated in the party's support for Slobodan Milosevic's Serbia during the war in Kosovo. The National Alliance (AN) was still paying the price of the burdensome legacy left by its predecessor, the MSI party, as well as its opposition to the Maastricht Treaty and the embarrassment over its dispute with Slovenia under the first Berlusconi government. ${ }^{1}$ Forza Italia also contained a hard, authoritative Euro-skeptic minority, including certain eminent players such as Antonio Martino and Giulio Tremonti. On the other hand, the parliamentary majority, the largest in the history of republican government, seemed to weaken the blackmailing potential of each of its individual components, while the majority of MPs belonging to the Casa delle Libertà (mainly members of Forza Italia and the UDC, and, at the European level, of the European Peoples' Party) supported a moderate, traditional form of foreign policy.

The eventual solution to these conflicting pressures was the personalization of Italian foreign policy through the involvement of the prime minister. Silvio Berlusconi's investment of his own personal political assets, which discouraged his allies from coming into direct conflict with their coalition leader, made it easier to keep the underlying divisions within the majority under control. At the beginning of the government's term of office, this personalization was revealed through the denial of the constitutional principle stating the cabinet's collegial responsibility. The principle whereby the definition of the basic guidelines of foreign policy was the prime minister's responsibility was reaffirmed on several occasions, while the minister of foreign affairs acted merely as a technical executor. ${ }^{2}$ Later, personalization assumed an even more unequivocal form when the prime minister took over the foreign ministry portfolio for 11 months before the eventual appointment of Franco Frattini, a true-blue disciple of Berlusconi who was independently chosen by the prime minister's office.

The personalization of Italian foreign policy, however, has not led to the separation of foreign policy from domestic politics. In fact, all 
charismatic leaderships suffer from certain structural weaknesses. ${ }^{3}$ Firstly, they tend to produce policies that are ephemeral by definition and that fail to outlive their creator. In democratic regimes, in which political roles are subject to a regular, frequent turnover, personalization inevitably leads to instability. ${ }^{4}$ Secondly, the country's international standing is weakened, since the government's leader, with whom the cabinet identifies, may decide to make special allowances in the field of foreign policy, should internal difficulties arise. Finally, personalization can easily lead to confusion between the leader's personal agenda and his public actions. There is a tendency, in fact, to mix domestic and international policy: on the one hand, foreign policy tends to be used as a source of internal legitimization; on the other, partly for the same reasons, preference is given to relationships with states governed by ideologically similar leaders. ${ }^{5}$

In Berlusconi's case, the combination of his political agenda with other types of considerations, such as his ownership of an industrial empire and his judicial problems, seems to confirm this assumption. ${ }^{6}$ In fact, the latest election victory raised serious international concern over the numerous investigations into the prime minister's conduct and over the thorny issue of his conflict of interests. ${ }^{7}$ The growing personalization of politics concerns not only the instruments of foreign policy but also its very objectives, including primarily the pursuit of legitimization on the domestic and international fronts. In other words, a sizable section of Italian foreign policy over the past year and a half has been motivated more by attempts to accredit an individual as being "equal" to other national leaders than by the overall needs of the country. Berlusconi's foreign policy has been erratic and opportunistic, aimed at pleasing the audience in question, rather than developing solid political guidelines. This explains certain tactless blunders made by the prime minister and the foreign minister and, in particular, the prime minister's inability to control his own personal opinions, as was clear to all in the case of the Berlin declaration, which we shall be looking at in more detail below.

As a result, Italian foreign policy wavers between continuity with the past and the desire to break with that same past. Two telling examples were Renato Ruggiero's resignation and the length of the following interim foreign ministry; they epitomized the government's persistent inability to find a lasting solution to the differing views on foreign policy-especially on the European question-within the governing majority. Only Berlusconi's control over the coalition could soothe the divisions between the pro-European section of the Casa delle Libertà and those who, like Minister of Reforms Umberto Bossi, accused the European Union of being a "gallowsland" (forcolandia) at 
the Laeken summit. ${ }^{8}$ Berlusconi, however, did not wish to trigger a domestic political crisis on foreign policy issues. In the words of one commentator, who is usually sympathetic toward the Italian prime minister, Berlusconi "avoided giving embarrassing explanations.... Europe, according to Berlusconi, was worth more than a ministerial squabble.... [Berlusconi] avoided all of the hurdles and all confrontation on questions of principle, and managed to maintain a position somewhere between Euro-skepticism ... and Euro-enthusiasm... although he never dispelled this doubt."

These were some of the reasons why Italian foreign policy opted for form rather than substance, and its success can therefore be measured only in terms of the prime minister's public relations. An "announcement policy" was pursued, hence the declaration that the interim foreign ministry was to last until completion of the administrative reform of the ministry itself, which in the end was not achieved. A "site-supplying policy" (politica della sede) was also pursued, which partially modified the traditional "chair-seeking policy" (politica della sedia), a derogatory expression indicating the Italian inclination to refrain from pursuing its own national interest in return for invitations to the most prestigious international negotiating tables. Under the Berlusconi government, what matters most is that Italy, or the prime minister himself, plays host to events at which several important announcements are to be made. Some noteworthy examples include the NATO summit held at Pratica di Mare and the Italian government's attempt to press for the closure of the European Convention works in the semester of the Italian presidency, in spite of the fact that Italy had not put forward any noteworthy proposals on that particular subject. ${ }^{10}$

In the end, Italian foreign policy turned out to be somewhat inadequate by the very standards the Casa delle Libertà had introduced. The most patent feature of the country's foreign policy since May 2001 has been a tendency to emphasize (at a formal rather than a substantial level) the rediscovery of so-called "national interests." Moreover, over the past few months Italy's renewed nationalization of foreign policy has emerged after a brief appearance under the first Berlusconi government between June 1994 and January 1995. ${ }^{11}$ However, it should also be noted that, a year and a half later, the frequent reworking of Italy's position, which may have earned the prime minister a few favors, has resulted in a considerable loss of credibility. Regardless of the pros and cons of the personalization of domestic policy, its cost on the international front has far exceeded any ensuing gains, due to the fact that in an unstable international system, reliability proves an invaluable resource. 


\section{The Early Days: The Berlin Declaration}

In the first few months of the second Berlusconi government, domestic politics stole the limelight from foreign policy and absorbed most of the government's time. ${ }^{12}$ Then, suddenly, the 11 September 2001 attack on the Twin Towers catapulted international policy to the very top of the government's agenda. After the immediate declarations of sympathy and support following the terrorist attack-designed to expose the atrocity of the attack but also to show Italy's closeness and loyalty to its American ally-an anti-terrorism coalition began to emerge, and within a few weeks Italy was involved in military action in Afghanistan. As the United States itself acknowledged, the success of this operation depended heavily on the support of certain moderate Arab countries such as Egypt, Pakistan, Yemen, and Jordan. Their involvement, however, would be possible only if the response to the attacks was not cast as a "crusade" against Islam. As a result, although the attacks continued to be condemned, the language of diplomacy gradually replaced more extreme expressions of anger.

In this climate, at the end of a meeting with Russian President Vladimir Putin in Berlin on 26 September, the Italian prime minister commented on the international scenario using words that were quickly condemned worldwide. After justifying the reaction to terrorist attacks as "a duty, a need, and a right," the Italian prime minister augured that this intervention would constitute the continuation of the West's mission to "civilize" the world of Islam, which in Berlusconi's view is an inferior civilization to that of the West, one that fails to respect fundamental human, political, and religious rights. ${ }^{13}$

Within the space of a few hours, these words had been broadcast around the world, causing considerable embarrassment and triggering a chain reaction among international institutions such as the European Union and several national leaders. Romano Prodi, the president of the European Commission, labeled the prime minister's words as unacceptable, and Guy Verhofstadt, the Belgian acting president of the European Council, deemed them "very dangerous" and capable of fueling existing tension between Islam and the West. Shortly afterwards, British Interior Minister David Blunkett also criticized Berlusconi, claiming not only that he had jeopardized all of the diplomatic efforts that had been made up until then to organize a wide and effective coalition in support of military intervention, but also that he had cast serious doubt over Italian involvement in this operation. ${ }^{14}$

Apart from their content, what was surprising about the prime minister's declarations was the total lack of timing with the efforts that international diplomacy had been making for weeks, as well as 
the failure to refrain from expressing an opinion that was wholly personal and as such uncalled for. As one American weekly suggested, there was one country in the West that was swimming against the tide, and that country was Italy. ${ }^{15}$ The Berlin declarations are an example of the prime minister's lack of experience and his unfamiliarity with the language of international diplomacy. Unfortunately, he was to repeat these mistakes again during the course of his office.

Of course, this does not mean that some, maybe several, of his critics did not privately share his views. In fact, a survey conducted soon after the incident showed that over half of the Italian population shared Berlusconi's views on Islam. ${ }^{16}$ Some Italian political representatives and intellectuals, although perhaps of a different political color than that of Berlusconi's coalition, claimed that when it came to Islam and the West, "Berlusconi was not totally wrong." 17 It clearly appears that to some extent, the prime minister's declarations epitomized certain widely held principles and feelings. However, his utterances eventually clashed with the setting in which they were made. While international diplomacy was very busy trying to involve other countries in the war against international terrorism, the Italian prime minister's views hardened feelings within the Arab League and astounded Egyptian President Hosni Mubarak. Just a few weeks earlier, Mubarak had been given a warm reception in Rome, and yet now he saw his country slipping into Berlusconi's "inferior" civilization category.

The Berlin incident had almost immediate consequences. It exacerbated doubts and apprehension concerning the tentative nature of Italian foreign policy, which bore the mark of a tendency toward expressing highly personal opinions in sensitive international settings. In fact, a few days before the European Union summit in Ghent on 19 October 2001, French President Jacques Chirac decided to call a meeting with his German and British counterparts to discuss the developments of the war in Afghanistan, a meeting from which Italy was excluded. This was immediately criticized by several Italian politicians, including the Italian president himself, as an attempt to create a new "tripartite directorate." 18 This incident, however, has also to be seen as a deliberate move to punish Italy by relegating it to the "second division" of European countries, due to the faux pas in Berlin. Moreover, a similar incident occurred just a few weeks later. This time, the person who allegedly tried to exclude Italy from tripartite talks between France, Great Britain, and Germany was Tony Blair. ${ }^{19}$ Thus, the effect of Berlusconi's declarations was to distance Italy from routine European diplomatic bargaining.

In a calculation that was eventually to prove mistaken, the prime minister saw the distance between Italy and its European partners as 
an opportunity to get closer to the United States; he therefore used the upcoming Afghanistan war to launch a charm offensive. Berlusconi was pleased to see Parliament ratify the sending of 2,700 troops to Afghanistan on 7 November, and was convinced that this was sufficient to make Italy an important ally in the war against terrorism. ${ }^{20}$ Furthermore, in the same period, in order to enhance Italy's Americanophile image, the prime minister took part in the "USA Day," a march of solidarity with the United States held in Rome and originally conceived as a non-partisan, independent rally, although it was soon to be co-opted by Forza Italia. The initial events stemming from the Berlin declarations thus revealed the changed handling of Italian foreign policy: not only had it become manifestly personalized, but it was also characterized by the sometimes bold pursuit of a higher international profile for the country.

\section{Between Continuity and Change: Ruggiero's Resignation}

Europe was going to be a truly critical test for Italian foreign policy, caught as it was between the will to reaffirm continuity with its federalist, Europhile past and the desire to affirm its diversity from this tradition. Moreover, the issue of the Airbus A400M military transport aircraft, followed by that of the international arrest warrant, led to significant splits within the Berlusconi government and eventually to the sensational resignation of Foreign Minister Renato Ruggiero. These events revealed to Europe and the world the unusual sight of a Euro-skeptic or, worse still, an anti-European Italy.

The Italian involvement in the Airbus project goes back rather a long way to the mid-1980s. In keeping with this tradition and with a view to boosting European industrial production in the defense sector, thereby counterbalancing American hegemony in this field, in July 2000 Defense Minister Sergio Mattarella signed Italy's participation in the construction of the A400M aircraft. In addition to the industrial value of the production of this plane, there was also a symbolic value-that of encouraging the creation of a joint European defense system, which Italy had traditionally called for.

Given this, Italy's decision to withdraw from the project, made on 24 October 2001 and announced by Defense Minister Martino (later confirmed by the prime minister), pointed to a sudden reversal in Italy's European policy. The government's U-turn came as a total surprise: the bewilderment and criticism from Germany, France, and Great Britain, the most committed supporters of the Airbus project, were echoed by grumblings from within the cabinet. Renato Ruggiero, 
who until then had managed to control his criticism of the prime minister's excesses and to formulate a foreign policy in keeping with both international expectations and Italy's traditional foreign policy line, finally came out and expressed his concern about the decision made, openly complaining that his advice on the matter had not been sought. ${ }^{21}$

A few weeks later, further details of this decision were made public, throwing light on the strategic calculations underlying the Italian defection. The Ministry of Defense announced that Italy was negotiating its involvement in the construction of the Joint Strike Fighter aircraft, the new American fighter-bomber that the Pentagon had commissioned to Lockheed Martin, the world leader in the defense industry. ${ }^{22}$ Italy was therefore caught up in a quandary: the choice of Europe or the United States, and in the end it chose its American ally. In contrast to its major European partners, including Great Britain, the Italian government saw the choice between Europe and the United States from the point of view of competition in a zero-sum game, which forced one to side with the strongest ally.

This incident was destined to mark the watershed in the second Berlusconi government's foreign policy. From that moment on, the Europhile position embodied by Ruggiero was to come into increasingly violent conflict with Berlusconi and Defense Minister Antonio Martino's Americanophile line and with the anti-European positions of Giulio Tremonti, Umberto Bossi, and, to a lesser extent, Rocco Buttiglione. Shortly afterwards, Ruggiero was to be faced with progressive isolation from within the government. At the end of November, while the foreign minister was expressing his satisfaction with the parliamentary vote in favor of the calling of a new European Intergovernmental Conference, which was to be established through the works of the European Convention, Italy spoiled the Laeken party ${ }^{23}$ by voting against the adoption of an international arrest warrant and by expressing criticism of, and raising objections to, new extradition procedures. ${ }^{24}$

These different currents within the government ended up overstepping the limit when the euro was introduced on 1 January 2002. When the new currency started circulating in the country, amid general satisfaction, some perplexity, and a good deal of media attention, the government's reaction was summed up in a few scornful declarations made by the prime minister (who stated that he never carried coins on him), in the dry comments made by Giulio Tremonti and Antonio Martino, who portrayed the euro as a business for technocrats, and in Umberto Bossi's bucolic verbal outpourings. ${ }^{25}$ Ruggiero's resignation as foreign minister came a few days later (6 January 2002), after he had accused the government of indifference toward a 
historic event for Europe, and after the prime minister's counteraccusation that it was he, Berlusconi, who decided Italian foreign policy, not a "technical" minister like Ruggiero. ${ }^{26}$ Thus it was that Silvio Berlusconi became the acting foreign minister, a position that he was to hold for 11 months. ${ }^{27}$ Naturally, this new institutional solution would have allowed the prime minister to make an even greater personal mark on foreign policies, as was indeed the case. This experimental solution, however, was severely criticized by the opposition, by Italian industry, and by international observers. ${ }^{28}$

\section{Italy and Multi-lateralism}

As illustrated above, Ruggiero's resignation coincided with an ambivalent policy (as opposed to Italy's traditional multi-lateral attitude) wavering somewhere between the affirmation of its ties with Europe and the West and the launching of a bolder bi-lateral policy. However, a propensity to personalize foreign policy, which was further heightened by Berlusconi's double involvement as head of the government and as foreign minister, inevitably facilitated the latter tendency. On the one hand, Berlusconi's exuberant style did not befit institutional procedures; moreover, he had less knowledge of international matters than his fellow foreign ministers, who did not hold two offices. On the other hand, a personalistic approach per se tends to privilege bi-lateral rather than multi-lateral relations; in particular, it attaches considerable value to the establishment of close diplomatic relations with the leaders of the most powerful states.

According to international relations theory, under normal conditions a country would prefer to abstain rather than jumping on the bandwagon of the leading states. In addition, a powerful ally is more difficult to control and needs less help from a weaker country. This is why states usually tend to avoid asymmetric alliances, opting instead for balanced coalitions. ${ }^{29}$ In the current framework of relations between great powers, these reasons should have led Italy to side with the other European powers in a joint attempt to influence American policies. However, as personal relations overshadowed the country's alignment, diplomatic relations became all the more important, the more powerful the counterpart was. This explains the personal alliances Berlusconi created with Bush and Putin-sealed by his visit to Camp David and by his friendship with the president of the Russian Federation and his family - at the cost of relegating Italy to a more marginal position within Europe. These newly established relations reached their peak during the NATO summit, when Italy 
once again played the role of "master of ceremonies" and the Italian prime minister that of mediator and spotlight chaser.

On 28 May, at Pratica di Mare, NATO met to announce the creation of a Council of Twenty that, for the first time, comprised Russia, too. This event, defined as "historic" by Berlusconi, actually raised a number of problems. ${ }^{30}$ As regards Russia's role within the Atlantic Alliance, Berlusconi espoused the views held by Bush and by American unilateralists, who were more inclined toward interest alignments, such as the one established with Moscow, than toward multi-lateral alliances. This evolution of NATO, however, was not necessarily a positive one for Europe, nor for Italy, as a result. Firstly, the political involvement of the Russian Federation would proportionally diminish NATO's military role. This role was more useful to Europe, which did not have any other unilateral alternatives, than it was to the United States. Secondly, the politicization of NATO caused by Russia's involvement seemed to be aimed at creating a legitimization forum for Western intervention as a possible alternative to the role played by the UN. In this case, too, this position was closer to Washington than to Brussels. Finally, Italy's predilection for a direct relationship with the United States could be seen in Italian views on the strategies for European enlargement. Italy was lukewarm toward the imminent round of accessions from the East and the South. On the contrary, it supported Turkey and Russia's entry into Europe, which came later in the EU agenda and which, despite its enormous economic implications, would bring about a profound change in the nature of the Union, through a considerable weakening of its political cohesion within a completely transformed geopolitical landscape. For example, one has only to consider the consequences that the accession of a country bordering China and Iran would have on Europe's fragile common foreign policy. This scenario would involve several risks for Europe, though it might be welcomed by the United States, since it would favor Turkey and Russia, its strategic allies.

Italy's decision to give preferential treatment to relations with the United States, to the detriment of relations with its EU partners, seems however to reveal three structural limitations that may undermine the effectiveness of this new direction in Italian foreign policy. Firstly, while Italy plays a key role in European foreign policy (due also to institutional design), it is not indispensable for the United States. From a military as well as a geopolitical viewpoint, Italy does not enjoy as much negotiating power in its dealings with the United States as it does in European multi-lateral discussions. Secondly, the United States' interest in Italy is in general directly proportional to its ability to influence EU policies. Abandoning the European priority 
would therefore have a number of negative long-term consequences for Italy's relations with Washington as well, since it would reduce the strategic importance that the country has for the United States. Thirdly, Italy does not seem to possess either the moral or the material resources required to provide concrete support to the United States according to the priorities set by Washington, particularly in a possible second Gulf war. Not only does Italy lack the military strength for any major intervention beyond basic diplomatic support, but Italian public opinion seems to be clearly against any such operation, and therefore constrains its charismatic leader, who pays considerable heed to electoral implications. From this point of view, the personalization of Italy's foreign policy represents a weakness, since Berlusconi, who lacks international legitimization from Europe and the UN, is unlikely to bring upon himself the consequences of an unpopular decision.

\section{The Middle East and the Iraqi Crisis}

Now that Italy has lost its long-established multi-lateral directionfinder, whereby it could measure its orientation against its partners' positions before embarking on actions that are difficult to pull out of, in recent months the Italian position has appeared to be rather volatile. With regard to the Middle East, for example, the Italian government has wavered between its traditional Europhile and Arabophile stance, and a bolder, more strong-willed position.

The one incident that truly revealed this wavering was the Bethlehem crisis in May 2002, when international attention was focused on Italy as it played a key role in the negotiations for the release of the Palestinians trapped in the Church of the Nativity. On that occasion, the government took most commentators by surprise and frustrated international expectations when it curtly refused to host the 13 Palestinian gunmen, despite strong pressure from the Vatican, Giulio Andreotti, the United States, and several other intermediaries. The government was determined not to let this proposal pass in order to raise Italy's profile in the Middle East and obtain recognition for the country's role. ${ }^{31}$

There were a number of reasons underlying this decision, some of them concerned with the long-term situation, others stemming from the current political situation and strategic calculations. They included Gianfranco Fini's and Umberto Bossi's intolerance toward the idea of hosting 13 Muslim terrorists; the attempt by the National Alliance party to get in Israel's good books, thereby obfuscating its 
own anti-Semitic origins; Berlusconi's desire to stand his ground in order to "make Italy count" and therefore to reaffirm his leadership status at the international level; the government's desire to detach itself from the pro-Arab line that Italian foreign policy had often dogmatically followed for the past 30 years at least; finally, the government's determination not to emulate Massimo D'Alema's center-left administration by receiving "thirteen little Ocalans." 32

The prime minister, in his pursuit of the "site-supplying policy" mentioned above, attempted to the very last to barter Italy's reception of the 13 Palestinians for the organization of an "International Conference for Palestine" to be held in Rome, albeit to no avail. ${ }^{33}$ After Italy had missed out on its chance to join the front ranks of international diplomacy, and thus to show Berlusconi to be a real international broker, the prime minister dug in his heels and demanded that the European Union, which the government had been belittling for several months, resolve the deadlock. Gianfranco Fini saw this crisis as "an excellent opportunity to start building a common foreign policy," while the prime minister suggested that Europe take responsibility for the 13 Palestinians trapped in the Church of the Nativity. ${ }^{34}$ After intense negotiations, an agreement was signed on 9 May 2002, following a meeting of the $15 \mathrm{EU}$ foreign ministers. It was decided that six EU countries, including Italy, would take in the Palestinian prisoners.

The worsening of the international situation and the possibility of an imminent war, this time against Saddam Hussein's Iraq, put an end to "smiling diplomacy." The threat of military action in Iraq showed that Italy, in spite of the efforts made by its prime minister, could not be "everybody's friend": the continued pursuit of this line would have led only to troublesome diplomatic incidents and dangerous indecision. Therefore, in September, at the margins of the European People's Party summit, Berlusconi announced that in spite of its friendship with the United States, Italy would support military intervention against Iraq only if the UN decided so. ${ }^{35}$ However, only two weeks later at the Copenhagen summit, he came to loggerheads with French President Jacques Chirac over the same issue. Berlusconi claimed that there was enough evidence to assume that "Iraq was building an implosion device and long-range missiles" and declared that it was time to "get a move on"; basically, he proposed a preventive attack. ${ }^{36}$ France rejected this proposal and announced that it would engage in aggressive stonewalling at the UN Security Council. At the same time, it acknowledged Italy's increasingly Americanophile position.

A few weeks later, Berlusconi had to reconsider his declarations once again. After a bi-lateral meeting with Vladimir Putin in Moscow 
on 16 October, which sealed the "special relationship" established between the two countries, Berlusconi claimed that Iraq no longer had any weapons of mass destruction and that Italy wished to follow a more cautious line than the one sought by Washington at the Security Council, adopting a stance very close to the French and Russian positions. ${ }^{37}$ The clarification given the following day, when it was stated that Italy remained "the United States' most loyal ally," did not help much to allay doubts or appease critics, or to reassure the world that Italy, after three radical policy changes in five weeks, did in fact have a coherent policy line regarding intervention in Iraq.

\section{Conclusions}

Since the very start of its term of office, the Berlusconi government has aimed at achieving a more strong-willed, high-profile foreign policy. There have been several underlying reasons for this strategy, such as the government's wish to distinguish itself from previous administrations, its desire to prove that the criticism and concern widely expressed in the international press were unjustified, and its attempt to make up for setbacks on the domestic front with successful achievements abroad. Within this context, and given the heterogeneous composition of the majority coalition, it was perhaps inevitable that the choice would have been for the greater international involvement of the coalition leader in order to achieve such a goal. This approach, however, also had the effect of undermining results: while charm offensives tend to remain superficial, the diplomatic blunders that can result from a highly personalized handling of foreign policy can lead to serious problems.

In an average-sized country such as Italy, even without all of these setbacks a charismatic strategy is going to yield poor results anyway. Although the fluidity of the post-bipolar international system means that states are not obliged to assume static positions, a country that changes its policy too frequently is bound to lose credibility. From this point of view, Italy's lukewarm attitude toward multi-lateralism and its predilection for a bi-lateral policy free from external constraints do not increase the country's basic autonomy; on the contrary, they seriously undermine its capability to exercise any influence over its allies' views. In fact, it does not look as if the above-mentioned events have bolstered Italy's European or global standing. Furthermore, the personalization of foreign policy can only produce a paradoxical outcome, since this kind of strategy, despite the incentive of raising the country's international profile, is bound 
to disappear together with the person who championed it, and will thus constitute a short interlude. On the other hand, this also means that the failures, as well as the achievements, of a personalized handling of foreign policy are only transitory and that Italy's status may therefore not be necessarily undermined in the long term.

Although the emergence of a charismatic leader in Italy appears to be a negative development, to some extent it is the logical consequence of the fragility of Italy's political system and of the weakness of party coalitions, which in the case of the center-right, have made identification with its leader a prerequisite for survival. Hence, it is quite surprising that the issue of the country's foreign policy, wherein personalization has probably revealed its greatest weaknesses over the last 18 months, has been virtually absent from the debate over institutional reforms. This may be the supreme proof that in Italy, the primacy of domestic policy over international affairs results in a complete lack of ideas on how to improve the projection of Italy's image abroad.

- Translated by Irene Forcella

\section{Notes}

1. On this topic, see Filippo Andreatta and Christopher Hill, "Italy," in The European Union and the National Defence Policy, ed. J. Howorth and A. Menon (London: Routledge, 1997). See also Filippo Andreatta and Christopher Hill, "Italy's Adaptation to the End of the Cold War: The Importance of Ideas on Foreign Policy," in Rethinking European Order: West European Responses, 1989-1997, ed. W. Wallace and R. Niblett (Oxford: St. Martin’s Press, 2000).

2. Such "private domain" is typical of those constitutions, such as the French one, that provide for a very different government structure than the Italian parliamentary system.

3. See Max Weber, Wirtschaft und Gesellschaft (Tübingen: Mohr, 1922).

4. Some exceptions to this "Weberian" rule-as was the case with Charles de Gaulle-arise when personalized features become institutionalized.

5. A typical example of an ideological fellowship between charismatic leaders was the special relationship between Margaret Thatcher and Ronald Reagan during the 1980s.

6. However, in Berlusconi's case, it would be more appropriate to talk about the "individualization" rather than the personalization of the handling of foreign policy. In fact, while the diplomacy of politicians such as de Gaulle or Konrad Adenauer can indeed be defined as personalized, Berlusconi's diplomacy is individualized insofar as the agenda-setting factors of the country's foreign policy are based on an individual's, rather than a nation's, priorities.

7. See, for example, "Why Berlusconi Is Unfit to Rule Italy," The Economist, 27 April 2002. See also C. Hill, "La politica estera del governo Berlusconi: 
un'opinione dall'estero," Ideazione, 7 September 2001 (http://www. ideazione.com/settimanale/1.politica/39_07-09-2001/hill.htm).

8. "Taormina e Castelli in piazza con la Lega," Corriere della Sera, 9 December 2001.

9. Sergio Romano, Guida alla politica estera italiana. Da Badoglio a Berlusconi (Milan: Rizzoli, 2002), 284.

10. This tendency, too, is part of the tradition of Italian diplomacy. For an illustration of this view in the process of European integration, see Anatonio Missiroli, "Italy," in The Foreign Policy of European Member States, ed. I. Manners and R. G. Whitman (Manchester: Manchester University Press, 2000).

11. R. Aliboni and E. Greco, "Foreign Policy Re-nationalization and Internationalism in the Italian Debate," in International Affairs 72, no. 1 (1996): 43-51.

12. Even the G8 summit held in Genoa was dealt with in terms of public order more than its actual content; also, its international dimension was mostly limited to its ceremonial aspects.

13. "Berlusconi: 'Attacco mirato senza vittime civili," la Repubblica, 26 September 2001; "Berlusconi: 'Occidente, civiltà superiore,'” Corriere della Sera, 27 September 2001.

14. "L'Europa sconfessa Berlusconi: 'Inaccettabili' le sue parole," la Repubblica, 27 September 2001; "La lega araba: razziste le frasi di Berlusconi," Corriere della Sera, 28 September 2001; "EU Deplores 'Dangerous' Islam Jibe,” BBC News, 27 September 2001; "Blunkett Attacks Berlusconi for 'Offensive' Comments on Islamic Culture," The Independent, 29 September 2001.

15. G. Edmonson, "Berlusconi's Accidental Gift to Bin Laden," Business Week, 22 October 2001 (http://www.businessweek.com/magazine/content/01_43/ b3754120.htm).

16. "Berlusconi corre ai ripari," la Repubblica, 28 September 2001.

17. C. Landi, "Ma della nostra civiltà dobbiamo essere orgogliosi," interview to Gianfranco Pasquino, Ideazione, 8 October 2001 (http://www.ideazione.com/ settimanale/2.esteri/43_08-10-2001/landi.htm).

18. Agence France-Presse, "Italian Press up in Arms over Mini-Summit Exclusion," 19 October 2001.

19. On that occasion, the Italian reaction managed to win the prime minister a last-minute invitation to dinner at Downing Street, where he turned up late in the evening: "Guess Who Wasn't Coming for Dinner" and "Better Late than Ever," The Economist, 10 November 2002.

20. In fact, the first Italian soldiers arrived in Kabul more than one year later.

21. "Italy and Europe: Berlusconi’s Foreign Policy," Financial Times, 26 October 2001.

22. G. Dragoni, "La marina e l'aviazione vogliono il JSF," Il Sole 24-Ore, 28 November 2001.

23. P. di Caro, "Nessun'altro paese gode di una maggioranza cosí ampia," interview to Renato Ruggiero, Corriere della Sera, 29 November 2001.

24. J. Graff, "The Italian Exception," Time, 17 December 2001. Many people saw Silvio Berlusconi's judicial problems reflected in these decisions, while Justice Minister Roberto Castelli voiced a more subtle concern, pointing out that after 50 years of integration, there were still profound differences between several judicial systems, which would have been difficult to harmonize all at once. This concern expressed a widely held view among members of the government, who were skeptical about the constitutional projects that Europe was committed to creating. It was also suspicious of those European institutions that embarked on projects of considerable social, political, and cultural 
importance. See F. Fubini, "Ecco la Bozza 'segreta' che fa discutere l'Europa,” Corriere della Sera, 31 August 2002.

25. F. Papitto, "Euro, Ruggiero all'attacco: 'Triste il silenzio del governo,'” la Repubblica, 3 January 2002. On 5 March, soon after the Northern League convention at which Bossi defined the European Union as a "fascist and Stalinist" construction, Ruggiero confirmed that Bossi's presence within the ruling coalition was one of the reasons for his resignation. The minister had already expressed his intention to resign on 12 December 2001, the day after Italy rejected the international arrest warrant. See R. Petrini, "Ruggiero rompe il silenzio: 'Con la Lega non potevo stare,”' la Repubblica, 5 March 2002.

26. S. Marroni, “'La politica estera la guido io e sulla UE non ho taciuto,” la Repubblica, 4 January 2002.

27. This was not the first case of an interim foreign ministry in the history of the Republic. The same thing happened under the governments headed by Badoglio (1943-1944), Bonomi (1944), Fanfani (1962), Moro (1964-1965 and 1965-1966), and Amato (1992).

28. S. Romano, "La posta in gioco," Corriere della Sera, 4 January 2002; P. Ignazi, "Dopo Ruggiero, una corsa ad ostacoli," Il Sole 24-Ore, 8 January 2002; "L'Ulivo: 'Ha vinto Bossi, per Berlusconi crisi disastrosa," la Repubblica, 5 January 2002; “L'Amarezza di Agnelli: 'L’Italia È Più debole,” la Repubblica, 6 January 2002; D. Williams, "Italy’s Foreign Minister Resigns: Exit Follows Flap Over Euro, Reveals Division on Nation's Role in EU," The Washington Post, 6 January 2002; P. Willian, "Euro Row in Prickly Pear Republic," The Guardian, 9 January 2002.

29. S. Walt, The Origins of Alliances (Ithaca: Cornell University Press, 1987); G. Snyder, Alliance Politics (Ithaca: Cornell University Press, 1997).

30. See "La Dichiarazione di Roma e l'Europa che verrà," Ideazione, 7 June 2002; and M. Kramer, "NATO, the Baltic States and Russia: A Framework for Sustainable Enlargement," International Affairs 78, no. 4 (2002): 731-756.

31. F. Venturini, "Un Lieve Imbarazzo," Corriere della Sera, 7 May 2002; R. Zuccolini, "Betlemme: Berlusconi dice no anche a Powell," Corriere della Sera, 8 May 2002; "Betlemme, l'ombra di Andreotti dietro la trattativa," la Repubblica, 7 May 2002.

32. This expression was used by Marco Follini, leader of the UDC, one of the government parties; see M. Giannini, "Fini: 'L’Europa si muova e l'Italia farà la sua parte,” la Repubblica, 8 May 2002. When Kurdish rebel leader Abdullah Ocalan was arrested in Italy in 1998, D’Alema, who was then prime minister, and the courts refused both to prosecute him for crimes against humanity and Turkey's request to extradite him (ostensibly because of the death penalty he faced there), eventually allowing him to flee the country.

33. P. Willan, "Road to Rome Blocked for Palestinian Militants," The Guardian, 8 May 2002.

34. Roberto Zuccolini, "Betlemme, l'Italia spinge per la soluzione europea," Corriere della Sera, 9 May 2002; P. Willan, "Israeli Surveillance Continues in Bethlehem Stand-Off,” The Guardian, 9 May 2002.

35. "Berlusconi: attacco solo nell'ambito dell'Onu," la Repubblica, 9 September 2002.

36. "Iraq, scontro Francia-Italia sulla tesi dell'attacco preventivo," la Repubblica, 23 September 2002.

37. Agence France-Press, "Berlusconi Distances Himself from Bush over Iraq," 17 October 2002; “'L'Iraq non ha armi devastanti' Berlusconi afferma e si smentisce," la Repubblica, 16 October 2002. 